\title{
Permainan Plasticine Sebagai Media Konseling Anak Pelaku Bullying Usia 5-7 Tahun
}

\author{
Fia Nurul Fauziah \\ Universitas Negeri Jakarta \\ Email: fianurul05@gmail.com
}

\begin{abstract}
ABSTRAK
Faktor utama pelaku bullying melakukan tindakan agresif dan mengusik orang lain yaitu ketidakmampuan mendefinisikan dan mengekspesikan emosi. Pentingnya penguatan positif dalam proses perkembangan dan pertumbuhan anak, khususnya memperkenalkan makna emosi dan bagaimana mengekspresikan emosi dengan baik. Penelitian ini bertujuan untuk mengelaborasi beberapa landasan teori mengenai tindakan bullying, emosi dan pelaksanaan konseling anak menggunakan media plasticine. Metode Penelitian yang digunakan adalah metode studi pustaka. Metode analisis data menggunakan metode analisis isi. Hasil Penelitian ini yaitu terelaborasinya landasan teori dan pelaksanaan konseling anak menggunakan permainan plasticine secara utuh yaitu meliputi: 1) pengelolaan emosi sebagai cara mereduksi agresivitas, 2) pelaksanaan konseling anak dalam kasus bullying, 3) tahapan konseling menggunakan permainan plasticine, 4) keunggulan media plasticine, 5) pengukuran parameter ketercapaian konseling menggunakan media plasticine.
\end{abstract}

Kata kunci : Bullying; Konseling Anak; Media Konseling Anak; Plasticine.

\section{ABSTRACT}

The main factor for bullies to act aggressively and to harass others is the inability to define and express emotions. The importance of positive reinforcement in the process of child developmentand growth, especially in introducing the meaning of emotions and how to express emotions well. This studyaims to elaborate several theoretical foundations regarding bullying, emotions and the implementation of child counseling using plasticine media. The research method used is literature studymethod. Methods of data analysis using content analysis methods. The results of this study are the elaboration of the theoretical basis and implementation of child counseling using plasticine as a whole, which includes: 1) managing emotions as a way to reduce aggressiveness, 2) implementing child counseling in cases of bullying, 3) counseling stages using plasticine games, 4) advantages of plasticine media, 5) measurement of counseling achievement parameters using plasticine media.

Keywords: Bullying; Child Counseling; Child Counseling Media; Plasticine.

(C) 2021 Fia Nurul Fauziah

Under the license CC BY-SA 4.0 
PEDAGOGIKA

Volume 12 (Nomor 1) 2021

HaL. 106-119

\section{PENDAHULUAN}

Bullying adalah tindakan upaya penyerangan, mengganggu, merusak ataupun mengusik orang lain yang umumnya lebih lemah dari pada dirinya. Menurut (Randall, 2002) bullying adalah perilaku agresif yang dilakukan seorang pelaku secara sengaja untuk mengganggu kenyamanan fisik dan psikologis korban. Faktor utama seorang anak melakukan bullying adalah karena ia tidak mampu mendefinisikan emosi apa yang terjadi pada diri mereka dan cara yang tepat untuk mengekspresikannya. Selain itu, orangtuanya cenderung tidak mau mendengar permasalahan mereka dan menggunakan kekerasan untuk membuat anaknya patuh. Menurut Mayer, Salovey, \& Caruso (2014) seseorang dengan kemampuan mengelola emosi yang rendah, cenderung lebih rentan melakukan tindakan kekerasan dan bullying.

Proses terjadinya bullying diawali dari sebuah peristiwa yang menyebabkan timbulnya emosi negatif pada anak. Selanjutnya emosi tersebut akan membawa seseorang pada pilihan untuk mengatasinya dengan melarikan diri atau menantang. Aspek menantang inilah yang dianggap sangat serius, sebab menjadi akar dari timbulnya perilaku agresif, bullying dan kekerasan (Yosep, 2007).

Perkembangan sosial anak didukung oleh kemampuan emosional yang anak miliki yaitu bagaimana mereka memahami emosi yang mereka alami dan mengekspresikannya. Kemampuan pemahaman emosi anak yang masih kurang baik akan mengakibatkan ketidakmampuan anak dalam memahami perasaannya, menyampaikan apa yang dia rasakan dan mengekspresikannya.

Menurut Patmonodewo dalam Hastuti, Fiernanti, \& Guhardja (2011) pemberian stimulasi yang dilakukan pada tahun-tahun pertama anak dapat memberikan dasar kualitas untuk kehidupan dalam waktu yang lama dan menentukan kesehatan jangka panjang. Hal tersebut karena ingatan mengenai keluarga sebagai orang yang paling dekat dengan anak sangat tertanam dalam memori mereka.

Pentingnya memberikan penguatan positif sejak dini dalam proses perkembangan dan pertumbuhan anak, terutama dalam memperkenalkan makna emosi dan bagaimana mengelola emosi dengan baik. Maka yang menjadi fokus utama bukan hanya pola perilaku anak yang dilatih agar bisa mengendalikan emosinya, 
PEDAGOGIKA

Volume 12 (Nomor 1) 2021

HaL. 106-119

namun juga memperbaiki perilaku bermasalah.

Konseling bagi pelaku bullying adalah solusi tepat untuk memperbaiki perilaku anak yang bermasalah, konseling anak akan lebih efektif jika menggunakan media-media pendukung oleh karena itu peneliti mengusung judul model permainan plasticine sebagai media pendukung konseling pada anak pelaku bullying di rusunawa pinus elok.

Permainan plasticine dapat membantu anak mengekspresikan emosi mereka, memproyeksikan emosi yang selama ini mereka pendam dan mengungkapkan perasaan-perasaan mereka alami. Sedangkan dalam konteks konseling permainan plasticine adalah media yang membantu konselor untuk mengidentifikasi perasaan dan emosi yang anak miliki berdasarkan bentuk-bentuk plasticine yang anak buat. Pentingnya penggunaan media dalam konseling anak yaitu agar anak dapat dengan leluasa mengungkapkan permasalahan dan emosi yang anak miliki.

Perkembangan anak usia 5-7 tahun termasuk perkembangan anak usia dini. Menurut Sit (2015) anak usia dini berada pada masa keemasan karena pada masa ini terjadi pekembangan yang sangat signifikan baik dari segi fisik maupun psikis. Perkembangan psikis yang dialami anak yaitu kemempuan berpikir, berinteraksi, pemahaman melalui indera, imajinasi, kemampuan Bahasa, kemampuan emosi, moral bahkan kemampuan memahami agamanya.

Menurut Nurmalitasari (2012) anak usia pra-sekolah belajar menguasai dan mengekspresikan emosi yang mereka miliki dengan cara memahami konsep emosi yang lebih kompleks, seperti kecemburuan, kebanggaan, kesedihan dan kehilangan, tetapi anak-anak masih memiliki kesulitan di dalam menafsirkan emosi orang lain. Anak memerlukan pengalaman pengaturan emosi untuk mengontrol dan mengarahkan ekspresi emosional, serta menjaga perilaku yang terorganisir ketika munculnya emosiemosi yang kuat dan untuk dibimbing oleh pengalaman emosional.

Seluruh kapasitas ini berkembang secara signifikan selama masa prasekolah dan beberapa diantaranya tampak dari meningkatnya kemampuan anak dalam mentoleransi frustasi. Kemampuan untuk mentoleransi frustasi ini, yang merupakan upaya anak untuk menghindari amarah dalam situasi frustasi yang membuat emosi tidak terkontrol dan perilaku menjadi tidak 
terorganisir. Menurut Hurlock dalam yang dia miliki dan memiliki toleransi yang Ni'matuzahroh \& Prasetyaningrum (2018) ciri-ciri penampilan emosi pada anak yaitu : rendah terhadap frustasi.

Sebagai seorang manusia tentunya 1) emosi bersifat sementara dan berubahubah; 2) reaksi yang kuat terhadap situasi yang menimbulkan rasa senang atau tidak sangat senang sangat kuat; 3) emosi itu sering timbul dan nampak pada perilakunya; 4) reaksi emosinya bersifat individual; 5) emosi berubah kekuatannya.

Menurut Owleus dalam Lembeck, O'Connor, Fluke, \& Peterson, 2012) (2012) bullying sebagai bagian dari agresi yang ditandai dengan 1) tindakan yang bertujuan, adanya niat mencelakakan; 2) pengulangan; dan 3) ketidakseimbangan kekuatan, biasanya korban tidak bisa mengimbangi dominasi pelaku. Selain itu, pelaku bullying cenderung mudah tersinggung, meledakledak dan memiliki toleransi yang rendah terhadap frustasi.

Menurut Mayer, Salovey, \& Caruso (2014) seseorang dengan kemampuan mengelola emosi yang rendah, cenderung lebih rentan melakukan tindakan kekerasan dan bullying. Dapat diartikan bahwa orang yang melakukan tindakan bully kepada orang lain sebenarnya adalah orang yang belum bisa mengendalikan diri dan emosi wajar jika memiliki masalah dan permasalahan tidak hanya dimiliki oleh orang dewasa saja, melainkan anak-anak. Banyak anak yang tidak bisa mengekspresikan emosi yang mereka rasakan, tidak bisa mengemukakan pendapat mereka dan juga beradaptasi dengan lingkungan. Anak-anak yang memiliki permasalahan seharusnya mendapatkan bantuan dari orang tua atau orang dewasa lainnya, ataupun konselor agar mereka dapat belajar cara menyelesaikan permasalahan tersebut.

Konseling pada anak agak berbeda dengan konseling pada umumnya, anak dan konselor memerlukan waktu yang cukup untuk saling mengenal dan membangun hubungan terapetik. Menurut Geldard \& Geldard (2012) konseling pada anak akan berlangsung efektif jika 1) adanya keterkaitan antara dunia anak dengan konselir; 2) eksklusif; 3) aman; 4) autentik; 5) rahasia dan memiliki batasan 6) tidak mencampuri; dan 7) memiliki tujuan. Ada tujuh keterampilan konseling anak yang perlu dikuasai oleh konselor anak. Keterampilan konseling anak tersebut 
meliputi 1) menjalin hubungan yang efektif dengan anak; 2) mengobservasi anak; 3) mendengarkan secara aktif; meningkatkan kesadaran dan pemecahan masalah untuk memfasilitasi perubahan; 5) menangani konsep diri anak dan kepercayaan yang merusak diri; 6) secara aktif memfasilitasi perubahan; dan 7) mengakhiri konseling.

Ada beberapa tahapan dalam konseling anak, menurut Geldard \& Geldard (2012) proses konseling anak terdiri dari 3 tahap utama yaitu:

1) penilaian awal, tahap ini bertujuan untuk mengumpulkan informasi anak dan masalah yang dimilikinya yang berasal dari informasi rujukan ataupun orang tua, orang tua dan konselor juga perlu melakan perjanjian terkait proses konseling yang akan dilaksanakan;

2) Terapi untuk anak, setelah mengetahui permasalahan yang dialami anak, konselor memilih media yang tepat berdasarkan usia, jenis kelamin, kepribadian dan permasalahan yang dialami anak. Setelah itu mulai bergabung dngan anak, mulai mengundang anak untuk bercerita atau mengungkan cerita yang dia miliki, memungkinkan anak melepaskan emosi yang mereka miliki dan memecahkan isu yang mereka miliki, memberdayakan anak dan membantu mereka berpikir dan berperilaku secara berbeda;

3) Tinjauan hasil terapetik, yaitu mengevaluasi kasus dan mengakhiri konseling.

Menurut Naumburg dalam Rubin (1988) penggunaan media secara ekspresif untuk mengungkapkan hal-hal yang ada dalam ketidaksadaran individu. Media digunakan untuk asosiasi bebas, diskusi dan interpretasi. Sedangkan menurut Khamer dalam Rubin (1988) media digunakan sebagai proses sublimasi yaitu bagaimana cara menggunakan impuls yang sulit diterima ke dalam bentuk yang dapat diterima secara social dan estetis. Dua pandangan ini memiliki perbedaan yaitu penggunaan media dalam terapis dan penggunaan media secara artistic.

Menurut Rubin (1988) penggunaan media dalam konseling anak terlihat tepat dan masuk akal, namun tidak begitu sederhana karena kadang anak merasa tidak nyaman untuk menggunakan media seni ketika mereka tahu itu akan dievaluasi. Hal yang harus dilakukan adalah melakukan pendekatan dengan konseli, membangun kepercayaan, kemudian konselor memilih media sesuai dengan tahapan perkembangan 
konseli. Seni dapat menenangkan dan menenangkan anak yang gugup, manipulasi tanah liat atau plastisin di tangan anak dapat menjadi pelumas yang luar biasa untuk komunikasi pikiran dan perasaan yang anak rasakan.

Menurut Land dalam Muro (1969) media yang dapat digunakan untuk melepaskan agresi yaitu tas bop, senjata, tentara, boneka karet, cat jari, tanah liat, dan adonan bermain. Ada Batasan-batasan penggunaan media dalam konseling yaitu: 1) batas waktu satu jam; 2) batasan dalam penggunaan media, yaitu, mainan hanya digunakan di ruang bermain; 3) batasan terhadap pelecehan fisik konselor; dan 4) batasan yang melarang anak masuk kembali ke ruang bermain pada hari tertentu jika ia memutuskan untuk pergi (Moustakas dalam Muro, 1969)

Konseling bagi anak-anak yang terindikasi melakukan agresivitas dan tidak bisa mengontrol emosi, konselor akan mengangkat tema-tema agresivitas dan mendorong konseli untuk menyalurkan agresivitasnya secara konstruktif kepada media kertas atau tanah liat yang sudah disediakan. Ketika mereka menyalurkannya secara konstruktif itu dapat membantu mereka mengendalikan emosi yang mereka miliki. Kemudian konselor mengajak diskusi secara alami dari perilaku anak dan karya seni yang dihasilkan, itu akan memiliki dampak yang jauh lebih besar daripada kegiatan yang dipentaskan. Selain itu anak harus diberi kesempatan untuk melihat, berpikir, bercerita, dan mengatakan apa yang muncul dalam pikiran mengenai seni yang mereka buat (Rubin, 1988).

Tanah liat adalah zat artistik yang jarang digunakan karena besar, berat dan penggunaannya berantakan. Namun, menurut Makin dalam Gladding (2011) tanah liat memiliki beberapa keunggulan yaitu : 1) dapat mengarahkan klien mengekspresikan diri secara konkret dan fokus; 2) bermain tanah liat juga dapat meningkatkan hubungan kerjasama antara klien dan konselor; 3) media yang cocok bagi banyak klien yang tidak bisa menatap konselor mereka, karena mereka tidak perlu melihat konselor ketika mereka membuat objek tanah liat; 4) selain itu, individu dapat menggunakan tanah liat untuk menurunkan dan mendapatkan wawasan dengan memanipulasi, memeras dan menumbuk tanah liat karena sangat lunak. Selain itu, menurut Atchison dalam Gladding (2011) dalam tanah liat dapat mengurangi kecemasan, menurunkan mekanisme 
pertahanan dan dapat berungsi sebagai objek yang dapat digunakan untuk memproyeksikan perasaan yang dirasakan konseli. Beberapa klien merasa lebih berdaya ketika bekerja dengan tanah liat daripada mereka melakukan banyak kegiatan dengan media lain.

Manipulasi tanah liat melalui hentakan, dorong, guling, trowing, juggling, atau gerakan lainnya memfasilitasi pelepasan energi dan ketegangan. Ekspresi bebas yang enerjik dapat menjadi tujuan itu sendiri, atau bisa mengarah pada pembentukan dari yang mengambil makna pribadi (Neukrug, 2015).

Menurut Geldard \& Geldard (2012) lempung adalah media yang dapat membantu anak mengekspresikan kemarahan, kesedihan, ketakutan dan kecemasan. Selain itu ada beberapa tujuan bermain lempung yaitu bisa membantu anak menuturkan dan berbagi cerita dengan cara memaknai lempung dan megilustrasikan apa yang mereka buat, anak bisa memproyeksikan perasaan yang mereka pendam ketika membantuk lempung sehingga perasaan itu bisa mereka kenali, membantu anak mengenali dan mengatasi masalah mendasar dan mengeksporasi kreativitas yang dia miliki. Penggunaan lempung bisa bermacam-macam cara yaitu bermain lempung, menggunakan lempung dalam masalah khusus, menciptakan dialog antara dua bentuk lempung ataupun bermain secara berkelompok.

Menurut Woltmann (2002) tanah liat, lempung, lumpur dan plasticine adalah media serupa yang dapat dikategorikan media tiga dimensi yang lentur. Perbedaannya tanah liat, lempung dan lumpur adalah media alami, sedangkan plasticine adalah media buatan yang dimodivikasi agar menjadi media yang lebih simple, bersih dan ringan. Plasticine lebih disukai anak-anak karena tidak mengeras dan dapat digunakan berulang kali. Menurut Woltmann dalam Woltmann (2002) plasticine bermanfaat untuk mereduksi sifat perilaku kontruktif, destruktif, agresif yang berulang yang jelas berbeda dengan perkembangan normal anak-anak dan pola permainan dan verbalisasi mereka.

\section{METODE PENELITIAN}

Penelitian ini menggunakan jenis penelitian yang berupa studi pustaka (library research). Studi pustaka berkaitan dengan kajian teoritis dan analisis dari berbagai referensi dan literatur ilmiah. Langkahlangkah metode studi pustaka dalam 
penelitian ini yaitu: 1) mengumpulkan data dan informasi melalui studi pustaka dari buku, jurnal, dan sumber lainnya; 2) Mengambil dan menggunakan sebagian atau seluruh data yang telah didapatkan; 3) Menganalisis data dan informasi untuk mencapai tujuan penulisan; 4) Mengkaji data dari hasil analisis dan pengolahan sehingga diperoleh kesimpulan penulisan.

Sumber data yang diperoleh dari literatur relevan yaitu buku dan berbagai artikel ilmiah yang relevan dengan topik yang dibahas. Teknik pengumpulan data yang digunakan dalam penelitian studi pustaka yaitu mencari data mengenai hal-hal atau variabel yang berupa catatan, buku, makalah, artikel, jurnal dan lain-lain (Arikunto, 2010). Teknik analisis data yang digunakan dalam penelitian studi pustaka adalah metode analisis isi (content analysis), yaitu proses pengkajian dan pengecekan antar pustaka dan membaca ulang pustaka yang sedang dianalisis.

\section{HASIL DAN PEMBAHASAN}

\section{Hasil}

Bullying pada anak menjadi salah satu kasus yang sangat pesat perkembangannya. Rendahnya kesadaran orang tua, lingkungan serta guru terhadap dampak bullying menjadikan kasus bullying semakin meningkat. Kasus bullying bisa terjadi dimanapun dan kapanpun, baik di lingkungan rumah ataupun sekolah. Rumah Susun Pinus Elok adalah rumah susun yang diperuntukan untuk warga relokasi dari bantaran waduk Ria Rio, waduk Pluit, kali Krukut Karet Tengsin, daerah rawan banjir Pedongkelan dan daerah rawan banjir lainnya. Ragamnya latar belakang penghuni menjadikan banyaknya budaya dan kebiasaan setiap warga, hal tersebut berarti perlunya adaptasi yang dilakukan oleh warga setempat, khususnya anak-anak. Lingkungan rumah yang berdekatan dengan rumah lainnya menjadikan anak beradaptasi dengan berbagai macam kebudayaan keluarga yang ada.

Anak-anak di Rumah Susun Pinus Elok memiliki semangat belajar yang tinggi, hanya saja perilaku mereka yang cenderung kasar dan berteriak-teriak terhadap sesama dan kurangnya pemahaman terhadap emosi yang mereka rasakan menjadikan mereka melakukan kekerasan baik secara verbal maupun fisik kepada teman-teman mereka. Anak-anak usia pra-sekolah yaitu usia 5-7 tahun sudah melakukan bullying terhadap teman mereka sendiri, bullying yang dilakukan seringnya secara verbal namun ada 
beberapa bullying secara fisik. Para pelaku bullying terbiasa untuk berteriak, berkata kasar dan menyudutkan korban. Perilaku seperti itu dapat dikategorikan kepada perilaku agresi yang dapat melukai korban secara mental maupun psikis.

\section{Pelaksanaan Konseling Anak dalam} Kasus Bullying

Bullying dapat terjadi kepada anak usia pra-sekolah, TK, SD, SMP, SMA, maupun tingkat Perguruan Tinggi. Pada jenjang pendidikan SMP dan SMA rata-rata telah memiliki guru bimbingan dan konseling yang dapat membantu mereka mengatasi permasalahan bullying di sekolah. Begitupun di Perguruan Tinggi ada Unit Pelayanan Terpadu Lembaga Bimbingan dan Konseling yang menyediakan konselor dan psikolog yang dapat membantu mereka menyelesaikan permasalahan bullying di perkuliahan. Sedangkan untuk kasus bullying yang terjadi pada anak-anak di lingkungan masyarakat, anak usia pra-sekolah dan anak SD belum terdapat guru bimbingan dan konseling atau konselor di lingkungan mereka.

Anak-anak yang kesulitan dalam beradaptasi di lingkunganya mendapatkan ancaman bully dari teman-teman dan tidak ada pihak yang dapat membantu mereka. Anak-anak yang melakukan bullying, kemungkinan akan terus merasa dominan dan melakukan kekerasan lain terhadap temantemannya, tidak ada orang yang membantu mereka keluar dari permasalahan agresivitas yang mereka alami sehingga mereka akan semakin menjadi pelaku bullying yang handal. Tidak adanya penanganan serius mengenai bullying di lingkungan sekitar tentunya menjadikan kasus bullying semakin marak di masyarakat.

Sedangkan pada kasus anak yang tinggal di perkotaan dan memiliki kemampuan ekonomi menengah keatas mungkin dapat mengajak anak-anak mereka mengikuti konseling dengan konselor professional, namun dalam kajian penelitian yang dilakukan di Indonseia masih sedikit yang membahas bagaimana proses konseling untuk anak-anak pelaku bullying menggunakan pendekatan art therapy ataupun play therapy. Rata-rata riset yang ditemukan yaitu bagaimana mengatasi permaslahan yang dialami oleh korban bullying, namun jarang yang mengunggap solusi terkait pelaku bullying.

Pengelolaan Emosi sebagai
Mereduksi Agresivitas
Perilaku agresi yang dilakukan
bullying adalah perilaku
menceriminkan yang

\section{$\underline{\text { Pedagogika.fip@ung.ac.id } \quad P-I S S N: ~ 2086-4469 Ｅ-I S S N: ~ 2716-0580 ~}$}


PEDAGOGIKA

Volume 12 (Nomor 1) 2021

HaL. 106-119

bullying mengelola emosi yang dia miliki. Karena menurut Mayer, Salovey, \& Caruso (2014) seseorang dengan kemampuan mengelola emosi yang rendah, cenderung lebih rentan melakukan tindakan kekerasan dan bullying.

Sebenarnya perilaku tindak kekerasan bisa dipelajari anak dalam role model keseharian mereka, misalnya orang tua dan tetangga di sekitar rumah. Banyak orangtua dan orang dewasa yang masih belum bisa mengendalikan emosi mereka sehingga anakanak dapat meniru apa yang mereka lakukan, oleh karena itu penting bagi kita sebagai pendidik mengajarkan bahwa emosi yang kita rasakan sebenarnya dapat kita kelola dengan baik.

\section{Pengaplikasian Permainan Plasticine}

Penggunaan plasticine dalam konseling dalam konseling sebagai media yang dapat membantu anak mengekspresikan emosi dan perasaan yang mereka miliki, mereka dapat memproyeksikan emosi ke dalam bentuk-bentuk atau pola yang mereka buat meggunakan plasticine. Ada banyak penelitian yang mengemukakan bahwa lempung adalah media yang tepat untuk menyelesaikan permasalahan emosi pada anak, namun lempung memiliki kekurangan yaitu berat, besar dan membuat anak mudah kotor. Sedangkan plasticine lebih bisa dimanfaatkan sebagai pengganti lempung karena lebih ekonomis, mudah ditemukan, dapat digunakan kembali dan tidak membuat anak mudah kotor.

\section{Pembahasan}

Penggunaan media permainan plasticine sebagai media konseling anak diharapkan dapat menjadi media alternatif pelaksanaan konseling bagi anak-anak khususnya usia dini. Media plasticine juga diharapkan dapat menjadikan solusi untuk mengurangi agresivitas anak dengan mengajarkan anak mengenai emosi dan pengendalian emosi selama proses konseling.

Permainan plasticine dapat digunakan dalam konseling untuk mengenalkan anak mengenai emosi dan cara pengendalian emosi. Plasticine dapat digunakan dalam beberapa model:

1. Media untuk mengekspresikan emosi

Anak akan mengekspresikan emosi dengan cara bermain plasticine dalam proses konseling. Ketika anak menggenggam, mengepal, memisahkan, menggabungkan, membentuk, melempar dan berbagai aktivitas motorik lain untuk mengemukakan emosi yang anak rasakan.

2. Media untuk proyeksikan emosi kedalam bentuk plasticine

Setelah anak membuat sesuatu, 
konselor menanyakan alasan anak tersebut membentuk figure yang telah dia buat. Kemudian konselor akan membantu anak untuk mendiskusikan mengenai perasaanperasaan yang anak miliki ketika bermain plasticine.

3. Media untuk berbagi cerita dari bentuk yang telah dibuat

Anak akan membentuk dua buah figure atau lebih, kemudian konselor mempersilahkan anak untuk menceritakan sebuah kisah yang bisa mengilustrasikan figure yang telah dia buat atau membagikan kisah yang dia miliki.

4. Media untuk menghadapi permasalahan khusus

Penggunaan plasticine dalam permasalahan khusus dilakukan ketika konselor sudah mengetahui permaalahannya dengan jelas, hubungan anak dengan konselor juga sudah dekat. Konselor akan meminta anak membuat suatu bentuk atau figure yang mewakili suatu perasaan yang anak miliki atau mewakili peristiwa tertentu. Setelah itu mereka akan berdiskusi mengenai bentuk yang konseli buat.

Tahapan Konseling menggunakan Permainan Plasticine

Konseling anak dengan media permainan plasticine dapat dilaksanakan dengan beberapa tahap yang diadaptasi dari Geldard \& Geldard (2012) yaitu:

1. Penilaian awal,

a. Menerima informasi rujukan

Kebayakan anak yang melakukan konseling karena rujukan dari orag tua mereka dan orang tua akan memberikan informasi mengenai anak dan permasalahan yang anak miliki berdasarkan sudut pandang orang tua.

b. Melakukan permengumpulkan informasi anak dan masalah yang dimilikinya

Setelah mengetahui informasi dari orang tua, pastikan kembali bahwa informasi yang diberikan orag tua valid. Konselor melakukan pendekatan dengan anak dan melakukan asesmen terhadap diri dan permalahan anak.

c. Sesi seluruh keluarga

Apabila konseling yang dilakan terintergrasi dengan terapi keluarga maka konselor juga harus memahami dengan baik permasalahan yang ada dalam keluarga konseli.

d. Perjanjian terkait proses konseling yang akan dilaksanakan

Perjanjian dapat dilakukan secara terbuka dengan mengutamakan kepentingan anak dan sebaiknya anak 
memahami hubungan konselor dan anak yang eksklusif.

2. Terapi untuk anak,

a. Memilih media yang tepat

Konselor memilih media yang tepat, dalam kasus bullying peneliti mengusulkan penggunaan permainan plasticine yang dapat membantu anak mengeksplorasi emosi yang dia miliki. Permainan plasticine dapat digunakan untuk mengekspesikan emosi, memproyeksikan emosi, menceritakan peristiwa tertentu dan memecahkan permasalahan khusus.

b. Melakukan pendekatan dengan anak

Konselor mengawali kegiatan dengan berkenalan, membuat situasi yang nyaman dan aman bagi, bisa dengan kehadiran orang tua mereka ataupun membuat anak memahami bahwa konselor adalah pihak yang aman bagi mereka.

c. Mengundang anak untuk bercerita atau mengungkan cerita yang dia miliki

Anak akan bercerita mengenai permaslaahannya, pada tahap ini konselor menggunakan media yang telah dipilih yaitu plasticine.

d. Memungkinkan anak melepaskan emosi yang mereka miliki dan memecahkan isu yang mereka miliki

Anak akan diajarkan bagaimana memandang suatu permasalahan dan mengidentifikasi permasalahan tersebut. Konselor tentunya membantu anak untuk memecahkan masalah yang mereka miliki.

e. Memberdayakan anak

Ketika anak terlihat sudah bisa menguasai isu yang ada, berikan pemahaman bahwa dia bisa berubah atau dia bisa mengendalikan dirinya sendiri atas permasalahan yang ada.

f. Membantu mereka berpikir dan berperilaku secara berbeda

Konselor membantu anak berpikir dan berperilaku secara berbeda, anak belajar untuk beradaptasi dengan perilaku tersebut.

3. Tinjauan hasil terapetik

a. Melakukan penilaian akhir dan mengevaluasi

Konselor bekerjasama dengan keluarga untuk melihat perkembangan anak.

b. Mengakhiri konseling

Ketika sudah ada perubahan dan dievaluasi, berikan penguatan positif kepada anak dan akhiri konseling.

\section{Keunggulan Media Plasticine}

Keunggulan media plasticine dibanding media lainnya yaitu harga terjangkau, mudah ditemukan lingkungan sekitar, ringan, dapat 
dibentuk kembali. Khususnya dalam konseling dapat dijadikan permainan yang membuat anak mengekspresikan emosi, mengeksplorasi emosi, bercerita dan memproyeksikan emosi anak.

\section{Pengukuran Parameter Ketercapaian} Konseling menggunakan Media Plasticine

Pengukuran keberhasilan konseling menggunakan media dapat telihat di konseling evaluasi dan terminasi. Jika ada perubahan mengenai pemahaman anak mengenai emosi, macam-macam emosi dan pengendalian emosi yang perlu dilakukan maka media plasticine dapat dikatakan efektif.

\section{SIMPULAN}

Permainan Plasticine merupakan permainan yang dapat membantu anak untuk mengekspresikan, memproyeksikan, memahami dan mengontrol emosi yang mereka miliki. Melalui permainan Plasticine, anak usia 5-7 tahun selaku sasaran utama dapat dengan mudah menjalani proses konseling dengan konsep bermain.

Tujuannya anak dapat memahami emosi yang mereka rasakan dan mengelola emosi tersebut, sehingga dapat menurunkan tingkat agresivitas anak, anak berinteraksi dengan baik di lingkungan social dan mengurangi tingkat bullying. Bagi pihak sekolah, permainan plasticine ini dapat digunakan oleh guru bimbingan dan konseling sebagai media dalam konseling anak.

Sebagai tindak lanjut dari pembuatan permainan plasticine sebagai media dalam konseling anak mengingkatkan pemahaman mengenai emosi, direkomendasikan beberapa hal sebagai berikut :

1. Permainan plasticine diharapkan menjadi media yang dapat digunakan oleh konselor dan Guru BK di sekolah.

2. Adanya program konseling di masyarakat sehingga anak-anak di lingkungan masyarakat dapat terbantu oleh tenaga professional.

3. Adanya dukungan dari lembaga kementrian Pendidikan untuk mewajibkan adanya konselor di TK dan $\mathrm{SD}$, sehingga dapat membantu anakanak yang memiliki masalah pengendalian emosi.

4. Menyarankan kepada seluruh orang tua untuk turut membantu anak dalam memahami emosi yang mereka miliki.

\section{REFERENSI}

Arikunto, S., \& Jabar, C. S. A. (2010). Evaluasi Program Pendidikan. Jakarta: Bumi Aksara

\section{$\underline{\text { Pedagogika.fip@ung.ac.id } \quad P-I S S N: ~ 2086-4469 ~ E-I S S N: ~ 2716-0580 ~}$}


Geldard, K., \& Geldard, D. (2012). Konseling Anak-anak. Jakarta: Indeks.

Gladding, S. T. (2011). The Creative Art in Counselling. United States: American Counseling Association.

Hastuti, D., Fiernanti, D. Y., \& Guhardja, S. (2011). Kualitas lingkungan pengasuhan dan perkembangan sosial dan emosi anak usia balita di daerah Rawan Pangan. Jurlal Ilmu Keluarga dan Konseling. Jurlal Ilmu Keluarga dan Konseling, 4(1), 57-65.

Lembeck, P., O'Connor, A., Fluke, S., \& Peterson, R. L. (2012). Bullying prevention and intervention. Student Engagement, 19.

Mayer, J. D., Salovey, P., \& Caruso, D. R. (2014). Emotional Intellegence: Theory, Findings and Implications. Psychological Inquiry, 15(3), 197-215.

Muro, J. J. (1969). Play Media in Counseling: A Brief Report of Experience and Some Opinions. Elementary School Guidance \& Counseling, 3(2), 104-110.
Neukrug, E. S. (2015). The Sage Encyclopedia of Theory in Counseling and Psychtherapy. United States: Sage.

Nurmalitasari, F. (2012). Perkembangan Sosial Emosi pada Anak Usia Prasekolah. BULETIN PSIKOLOGI, 23(2), 103-11.

Prasetyaningrum, \& Ni'matuzahroh. (2018). Observasi : Teori dan Aplikasi Dalam Psikologi. Malang: Universitas Negeri Malang.

Randall, P. (2002). Bullying in adulthood: Assessing their bullies and their victim. New York: BrunnerRoutledge.

Rubin, J. A. (1988). art counseling: an alternative. Elementary School Guidance \& Counseling, 22(3), 180-186.

Sit, M. (2015). Psikologi Perkembangan Anak Usia Dini. Medan: Perdana Publishing.

Woltmann, E. G. (2002). Mud and Clay. In C. E. Schaefar, \& D. M. Cangelosi, Play Therapy Techniques (p. 185). London: Jason Aronson Inh.

Yosep, I. (2007). Keperawatan Jiwa. Banding: Refika Aditama. 